GAO

Report to the Ranking Minority

Member, Committee on Health,

Education, Labor, and Pensions,

U.S. Senate

July 2005

\title{
NO CHILD LEFT \\ BEHIND ACT
}

\section{Most Students with}

Disabilities

Participated in

Statewide

Assessments, but

Inclusion Options

Could Be Improved

The information contained in this report has been updated in GAO-06-194R, dated October 28, 2005.

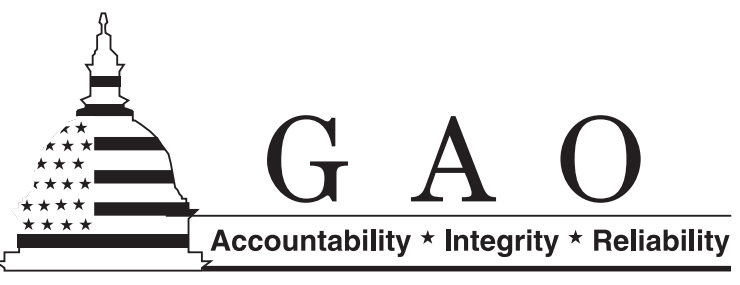




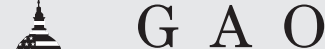 Highlights}

Highlights of GAO-05-618, a report to the Ranking Minority Member, Committee on Health, Education, Labor, and Pensions, U.S. Senate

\section{Why GAO Did This Study}

The No Child Left Behind Act of 2001 has focused attention on improving the academic achievement of all students, including more than 6 million students with disabilities and requires that all students be assessed. Students with disabilities may be included through accommodations, such as extended time, or alternate assessments, such as teacher observation of student performance. To provide information about the participation of students with disabilities in statewide assessments, GAO determined (1) the extent to which students with disabilities were included in statewide assessments; (2) what issues selected states faced in implementing alternate assessments; and (3) how the U.S. Department of Education (Education) supported states in their efforts to assess students with disabilities.

\section{What GAO Recommends}

GAO recommends that Education explore ways to make information about inclusion of students with disabilities more accessible on its Web site and work with states, particularly those with high exclusion rates, to explore strategies to reduce the number of students with disabilities who are excluded from the NAEP assessment. In comments, Education officials noted that they were taking actions that would address our recommendations.

www.gao.gov/cgi-bin/getrpt?GAO-05-618.

To view the full product, including the scope and methodology, click on the link above. For more information, contact Marnie S.

Shaul at (202) 512-7215 or shaulm@gao.gov.
NO CHILD LEFT BEHIND ACT

\section{Most Students with Disabilities Participated in Statewide Assessments, but Inclusion Options Could Be Improved}

\section{What GAO Found}

In the 2003-04 school year, at least 95 percent of students with disabilities participated in statewide reading assessments in 41 of the 49 states that provided data. Students with disabilities were most often included in the regular reading assessment, and relatively few took alternate assessments. Nationwide, the percentage of students with disabilities who were excluded from the National Assessment of Educational Progress (NAEP) was 5 percent, but varied across states, ranging from about 2 percent to 10 percent in 2002. Among the reasons for exclusion were differences in accommodations between states and the NAEP and variation in decisions among states about who should take the NAEP.

Participation Rates on Statewide Reading Assessments in the 2003-04 School Year for Students with Disabilities

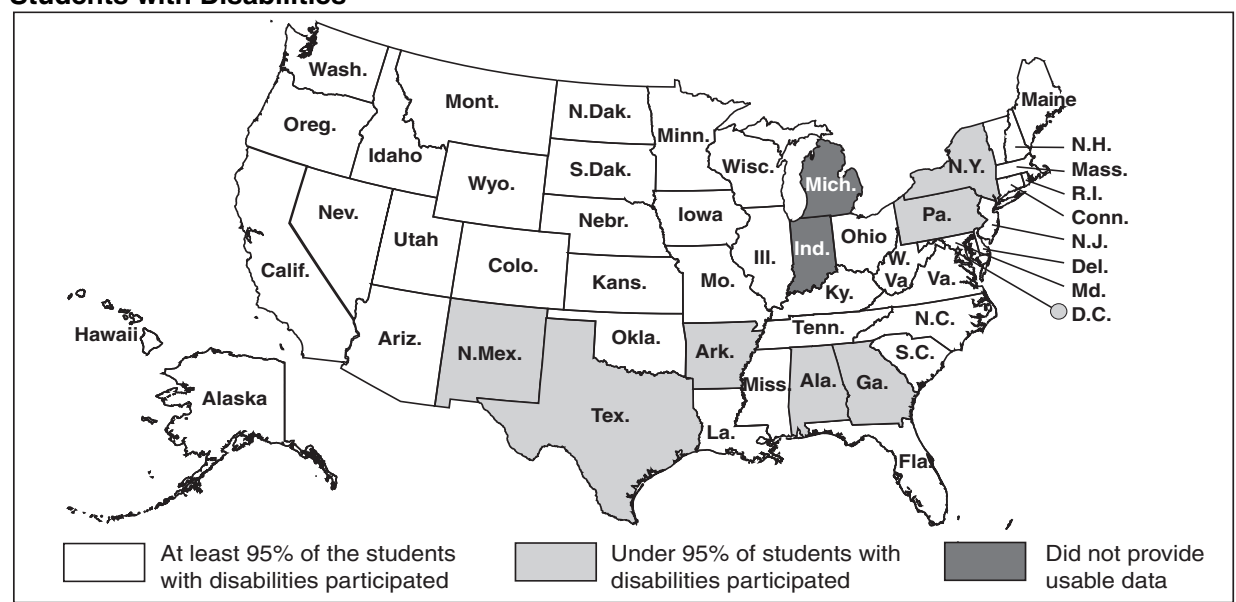

Source: State data reported to Education in consolidated reports.

National experts and officials in the four states we studied told us that designing and implementing alternate assessments was difficult because these assessments were relatively new and the abilities of students assessed varied widely. Officials in two states said they were not using an alternate assessment measured on grade-level standards because they were unfamiliar with such assessment models or because of concerns that the assessment would not appropriately measure achievement. In addition, learning the skills to administer alternate assessments was time-consuming for teachers, as was administering the assessment.

Education provided support to states on including students with disabilities in statewide assessments in a number of ways, including disseminating guidance through its Web site. However, a number of state officials told us that the regulations and guidance did not provide illustrative examples of alternate assessments and how they could be used to appropriately assess students with disabilities. In addition, our review of Education's Web site revealed that information on certain topics was difficult to locate. 


\section{Contents}

\section{Letter}

Results in Brief

Background

Most Students with Disabilities Participated in Statewide Reading

Assessments in the 2003-04 School Year

States Faced Challenges in Designing and Preparing Teachers to

Administer Alternate Assessments

Education Disseminated Information to States on Assessing

Students with Disabilities, but Some State Officials Reported the

Need for Alternate Assessment Examples 24

Conclusions

Recommendations for Executive Action

Agency Comments and Our Evaluation

\section{Appendix I}

Percent of Students with Disabilities Participating in State Reading/Language Arts Assessments in the 2003-04 School Year, by State

\section{Tables}

Table 1: Examples of Assessment Types by Achievement Standards

Table 2: Massachusetts' Data on How Students with Different

Types of Disabilities Were Included in Statewide Reading Assessments in the 2003-04 School Year

Table 3: Accommodations Provided in Some Regular Statewide Assessments but Not for NAEP

Table 4. Selected Alternate Assessments Used in Study States and Descriptions 


\section{Figures}

Figure 1: Distribution of State and the District of Columbia Participation Rates on Statewide Reading Assessments in the 2003-04 School Year

Figure 2: Distribution of States and the District of Columbia by the Percentages of Students with Disabilities Who Received Alternate Assessments Measuring Grade-Level and Below Grade-Level Standards in the 2003-04 School Year

Figure 3: Example of How a Below Grade-Level Standard Differs in

Complexity from a Grade-Level Standard

\section{Abbreviations}

ESEA Elementary and Secondary Education Act of 1965

IDEA Individuals with Disabilities Education Act

IEP Individualized Education Program

NAEP National Assessment of Educational Progress

NCLBA No Child Left Behind Act of 2001

OESE Office of Elementary and Secondary Education

This is a work of the U.S. government and is not subject to copyright protection in the United States. It may be reproduced and distributed in its entirety without further permission from GAO. However, because this work may contain copyrighted images or other material, permission from the copyright holder may be necessary if you wish to reproduce this material separately. 
July 20, 2005

The Honorable Edward M. Kennedy

Ranking Minority Member

Committee on Health, Education,

Labor, and Pensions

United States Senate

In the 2003-04 school year, more than 6 million students with disabilitiesapproximately 13 percent of all students—attended U.S. public schools. In an effort to improve the academic achievement of all students, including those with disabilities, the No Child Left Behind Act (NCLBA) of 2001 requires that states, districts, and schools are held accountable for their students' academic performance. Like all students, those with disabilities must be included in statewide assessments of achievement under the NCLBA. Assessments for students with disabilities are also required under the Individuals with Disabilities Education Act (IDEA). States must provide options to ensure that students with disabilities are included in annual assessments. States need to offer accommodations to meet these students' needs, for example, by giving them more time to take the same assessment as other students. States also are required to offer alternate assessments that measure students' performance at the same grade-level standards or at below grade-level standards. ${ }^{1}$ For example, students with the most significant cognitive disabilities could be assessed on their knowledge of academic content, such as fractions, by having to split groups of objects into two, three, or equal parts. Separately, under NCLBA, states participate periodically in the National Assessment of Educational Progress (NAEP), which provides a national picture of student academic achievement and a common measure of student achievement across states.

Questions have been raised, however, about the extent to which students with disabilities have been included in statewide assessments and whether these assessments accurately reflected student performance. Given your interest in these issues, we are providing you with information about (1) the extent to which students with disabilities were included in statewide assessments; (2) what issues selected states faced in implementing

\footnotetext{
${ }^{1}$ The term below grade-level standards refers to alternate achievement standards.
} 
alternate assessments; and (3) how the U.S. Department of Education (Education) supported states in their efforts to assess students with disabilities.

To obtain this information we used multiple data collection methods. To provide a national perspective, we reviewed and verified data on statewide assessments for the most recent school year available, 2003-04, from the State Consolidated Performance Reports provided by state officials to Education. Complete data were not available for mathematics assessments. Thus, we only verified reading-assessment data. ${ }^{2}$ This included data from 48 states and the District of Columbia on the participation rate of students with disabilities in assessments and data from 50 states and the District of Columbia on the types of assessments in which students with disabilities were included. Two states did not provide participation rate data in a usable format for students with disabilities, and one of these states also did not do so for all students. We also interviewed national education organization representatives and assessment experts. Second, we made site visits to four states-Florida, Iowa, Massachusetts, and Oregon - to collect in-depth information from state, district, and local officials. We selected these states to obtain variance in the participation rate of students with disabilities in statewide assessments, the type of alternate assessment data available in each state, innovative state approaches to assessment, and the availability of state assessment data for students with disabilities. We reviewed several national studies on the effects of students being excluded from NAEP and determined they were reliable for the purposes for which we used them. We also analyzed Education's documents and Web site, legislation, and other materials related to the assessment requirements for students with disabilities. We conducted our work between September 2004 and June 2005 in accordance with generally accepted government auditing standards. assessments in the 2003-04 school year, according to data collected by Education. Of the 48 reporting states and the District of Columbia, 41 states reported that at least 95 percent of students with disabilities

\footnotetext{
${ }^{2}$ To assess the reliability of the reading data, we contacted all 50 states plus the District of Columbia to confirm and clarify the data provided. We corrected identified reporting errors and determined that the resulting data set was sufficiently reliable for the purposes of our report. The 2003-04 school year was the first year for which states were asked to report on the participation rate of students with disabilities in statewide assessments.
} 
participated in the statewide reading assessment. The remaining states and the District of Columbia reported lower participation rates. Two states did not provide participation rate data for students with disabilities in a usable format. State participation rates for students with disabilities were generally similar to participation rates for all students. Most students with disabilities took regular reading assessments, and relatively few students with disabilities took alternate assessments. Two of the four states that we visited, Massachusetts and Oregon, used innovative approaches to measure the performance of students with disabilities, according to special education experts. For example, Massachusetts used an alternate assessment that lets students with widely varying abilities demonstrate their understanding of the same content standards. Nationwide, about 5 percent of students with disabilities were excluded from the NAEP reading assessment. Because states had different exclusion rates, ranging from 2 percent to 10 percent in the 2002 NAEP, comparisons of student achievement across states may have limitations.

State officials reported that providing alternate assessments was challenging, particularly because of the time and expertise required to design such assessments and the training necessary for teachers to implement them. National experts and officials in the four states we studied told us that designing and implementing alternate assessments that measured achievement of students with disabilities was difficult for a number of reasons, including these students' widely varying abilities. Officials in two site-visit states also reported that they were not using alternate assessments based on grade-level standards because officials were unaware of models of such assessments that appropriately measured achievement. In addition, national experts and officials told us that teachers needed training over a period of 2 to 3 years to administer alternate assessments properly. Teachers we spoke with told us that learning the skills to administer an alternate assessment was timeconsuming, as was administering the assessment.

Education provided support to states on including students with disabilities in statewide assessments through actions such as disseminating guidance, reviewing state assessment plans, awarding grants to help states improve their assessment systems, and conducting on-site visits. In assisting states, Education made extensive use of its NCLBA Web site, newsletters, and presentations at national education conferences to disseminate information on the requirements for including students with disabilities in statewide assessments. The department also funded two national centers that had, as part of their focus, the assessment of students with disabilities - the National Center on 
Educational Outcomes and the National Alternate Assessment Center. However, a number of state education officials told us that some specific information on how alternate assessments based on grade-level standards could be used appropriately to assess students with disabilities was lacking. Further, representatives from a national education organization said that many states were unfamiliar with models of this type and that examples would be helpful. In addition, we found that Education's regulations and clarifying information did not provide illustrative examples of what alternate assessments looked like and how they have been used to appropriately assess students with disabilities using gradelevel or below grade-level standards. During our review, we told Education about states' alternate assessment concerns. In May 2005, Education announced additional efforts to help states use alternate assessments. As part of this effort, Education plans to develop training materials and provide comprehensive technical assistance to states that lack alternate assessment plans for students with disabilities. In addition, our review of Education's Web site disclosed that information on certain topics related to the assessment of students with disabilities was difficult to locate. For example, there was no Web link that associated the alternate assessment information on the NCLBA section of the Web site with related information on the research, development, and use of these assessments that is available on other sections of Education's Web site.

We are recommending that the Secretary of Education explore ways to make information about inclusion of students with disabilities more accessible on Education's Web site and work with states, particularly those with high exclusion rates, to explore strategies to reduce the number of students with disabilities who are excluded from the NAEP assessment.

In comments on a draft of this report, Education officials noted that they were taking actions that would address the recommendations in this report. According to Education officials, the department will explore the use of "hot buttons" and links among the Web pages maintained by different Education offices and explore strategies for enhancing the inclusion of students with disabilities in the NAEP assessment. can have a wide range of physical and psychological disabilities, from severe cognitive delays or emotional disorders to specific learning disabilities that can affect their ability to learn. In addition, students with the same disability may demonstrate different levels of academic aptitude 
and achievement. Individual students with disabilities may demonstrate grade-level or above achievement in some academic areas, while at the same time demonstrating lower academic achievement in other areas. Finally, students with disabilities may require different approaches to assess their performance.

Two federal laws specifically require states to administer assessments for students with disabilities: NCLBA and the Individuals with Disabilities Education Act (IDEA) last amended in 2004. NCLBA, which reauthorized the Elementary and Secondary Education Act, was designed to improve academic achievement for all students. NCLBA requires that students with disabilities be included in statewide assessments that are used to determine whether schools and districts meet state goals. Further, NCLBA requires that all students, including students with disabilities, be measured against academic achievement standards established by the states. ${ }^{3}$ Specifically, NCLBA requires annual participation in assessments in third through eighth grades and one high school grade for reading and mathematics by the 2005- 6 school year. To be deemed as making progress, each school must show that the school as a whole, as well as each of designated groups such as students with disabilities, met the state proficiency goals. Schools must also show that at least 95 percent of students in grades required to take the test have done so. ${ }^{4}$ Further, schools must also demonstrate that they have met state targets on another measure of progress - graduation rates in high school or attendance or other measures in elementary or middle schools.

Under NCLBA, states are required to participate in NAEP for reading and math assessments in grades four and eight, although student participation continues to be voluntary. The purpose of this requirement was to use NAEP scores as confirmatory evidence about student achievement on state tests. According to Education, confirming state test results represented a new formal purpose for the NAEP. Also called "The Nation's Report Card," the NAEP has been conducted regularly since 1969. Since then, this assessment has provided a national measure of student

\footnotetext{
${ }^{3}$ NCLBA's focus on improving academic achievement for all students, including those with disabilities, has led to changes in what is taught to students with disabilities. For example, special education teachers historically taught their students a primarily functional curriculum. Students with significant cognitive disabilities learned, for example, how to tie their shoes and how to shop in stores independently rather than strictly academic content.

${ }^{4}$ In order to account for changes in participation numbers, Education allows schools to average their assessment results and participation rates over a period of up to 3 years.
} 
achievement. The NAEP can be used to track trends in student achievement over time or to compare student performance in a particular state with the national average. In 1996, Education developed a new inclusion policy that provided for accommodations allowing most students with disabilities ${ }^{5}$ to participate meaningfully in the NAEP. This policy was developed in response to increases in the numbers of students with disabilities, the attention paid to their needs, and a corresponding demand for information about their academic progress. Under the old policy, far fewer students with disabilities had been included in testing.

IDEA is the primary federal law that addresses the educational needs of children with disabilities, including children with significant cognitive disabilities. The law mandates that a free appropriate public education be made available for all eligible children with disabilities, requires an individualized education program ${ }^{6}$ (IEP) for each student, the inclusion of students with disabilities in state and district assessments, and requires states to provide appropriate accommodations for students who can take the regular assessment and to develop alternate assessments for students who cannot participate meaningfully in the regular assessment. The IEP team, which develops the IEP, also decides how students with disabilities participate in assessments, either without accommodations, with accommodations, or through alternate assessments.

Accommodations alter the way a regular assessment is administered. They provide students with disabilities the opportunity to demonstrate their academic achievement on a regular assessment without being impeded by their disabilities. For example, a student may need extended time to finish the assessment or someone to read the instructions aloud. Another example of an accommodation is taking the assessment in a small group setting.

Alternate assessments are designed for the relatively few students with disabilities who are unable to participate in the regular statewide assessment, even with appropriate accommodations. For example, a

\footnotetext{
${ }^{5}$ And English language learners.

${ }^{6}$ The term individualized education program refers to a written statement that is developed for each student with a disability that specifies, among other components, the services that a student will receive, the extent to which the student will participate in the regular education setting with nondisabled peers, and how the student will participate in statewide assessments.
} 
student with the most significant cognitive and physical disabilities may be able to communicate only through moving her eyes and blinking. An alternate assessment for this student could include teacher observation reports and samples of student work. Similar to the regular assessments, NCLBA requires that alternate assessments be aligned with the state's achievement standards. However, these assessments may be scored against grade-level or below grade-level achievement standards. See table 1 for examples of assessment types and achievement standards.

Table 1: Examples of Assessment Types by Achievement Standards

\begin{tabular}{lll}
\hline Assessment type & $\begin{array}{l}\text { Achievement } \\
\text { standard }\end{array}$ & Example \\
\hline $\begin{array}{l}\text { Regular assessment without } \\
\text { accommodations }\end{array}$ & Grade-Level & $\begin{array}{l}\text { Paper and pencil assessment, i.e., } \\
\text { the same assessment that students } \\
\text { without disabilities take }\end{array}$ \\
\hline $\begin{array}{l}\text { Regular assessment with } \\
\text { accommodations }\end{array}$ & Grade-Level & $\begin{array}{l}\text { Paper and pencil assessment with } \\
\text { extended time for test-taking; small } \\
\text { group or individual setting }\end{array}$ \\
\hline Alternate assessment & $\begin{array}{l}\text { Grade-Level or } \\
\text { below grade-level }\end{array}$ & $\begin{array}{l}\text { Portfolio showing samples of } \\
\text { student work }\end{array}$ \\
\hline
\end{tabular}

Source: National Center on Educational Outcomes.

An alternate assessment based upon grade-level achievement standards reflects the same standards as the regular assessment. For example, a student with an emotional disability, who might do her best work while being supervised, could solve an algebraic problem for a missing variable that is similar to items on the regular assessment while her teacher observed her perform the task correctly. Because the items are similar in complexity, the alternate assessment-observing the student performing the academic task correctly-would measure the same grade-level achievement standard as the regular assessment. For some students who could not be accommodated on the regular assessment, this method allows them to demonstrate their knowledge of grade-level academic content.

An alternate assessment based upon below grade-level achievement standards reflects standards that are less complex than those on the regular assessment. In contrast to a student solving an algebraic problem for a missing variable, a student with a cognitive disability could determine which coin is missing from a set of coins while his teacher records his efforts on a videotape. For some students, the alternate assessment allows them to demonstrate their knowledge of academic 
content at their individual developmental levels. Education's guidance states that these below grade-level standards are appropriate only for students with the most significant cognitive disabilities. The guidance placed no limit on the number of students that could be assessed against these standards. Under NCLBA, states and districts can count the proficient scores of students taking assessments with below grade-level standards as meeting state achievement goals provided the number of these students does not exceed 1 percent of all students. ${ }^{7}$

In addition, Education announced a new policy in April 2005 allowing states additional flexibility in assessing some students with disabilitiesthose who are not significantly cognitively disabled, but face considerable challenges in their academic development. For example, some students with disabilities may be 3 to 5 years behind their peers academically. The additional flexibility allows states to assess more students using less complex or below grade-level achievement standards. Further, qualified states were allowed to count the scores of these students as meeting state achievement goals, as long as the number of proficient scores for these students did not exceed 2 percent of all students.

Most Students with Disabilities Participated in Statewide Reading Assessments in the 2003-04 School Year
Most students with disabilities participated in statewide reading assessments in the 2003-04 school year. Students with disabilities were usually included in the regular reading assessments and sometimes were included in alternate assessments. Two states that we visited, Massachusetts and Oregon, had developed innovative approaches to including students with disabilities in statewide assessments. According to Education, 5 percent of students with disabilities were excluded from the NAEP, but state exclusion rates varied. This was in part because the assessment does not allow accommodations that are permitted on some statewide assessments.

\footnotetext{
${ }^{7}$ Education has offered to raise the 1-percent limit on the number of students who can be counted as meeting state achievement goals using below grade-level standards if a state demonstrates that it has a larger population of students with the most severe cognitive disabilities. For example, the limit has been raised for two states, Ohio and Virginia, to between 1.1 percent to 1.3 percent. For information on Education's policy regarding the inclusion of students in alternate assessments, see U.S. Department of Education, The Achiever, Jan. 15, 2004. http://www.ed.gov/news/newsletters/achiever/2004/011504.html.
} 


\section{Most Students with Disabilities Participated in Reading Assessments, and Participation Rates Were Similar to Those of Nondisabled Students}

Most students with disabilities participated in statewide reading assessments in the 2003-04 school year according to state reports to Education. ${ }^{8}$ Forty-one states reported that they met NCLBA's participation requirement by having at least 95 percent of students with disabilities participate in statewide reading assessments. Seven states and the District of Columbia reported participation rates below 95 percent for students with disabilities. Two states did not provide participation rate data for students with disabilities in a usable format. The participation requirement is part of what is considered to determine whether states, districts, and schools demonstrate adequate yearly progress. There are programmatic implications for not demonstrating progress goals. Two states, Indiana and Michigan, did not provide these data in a form that we could report. Figure 1 presents the distribution of participation rates on statewide assessments.

\footnotetext{
${ }^{8}$ Data from three states that we visited showed that the participation of students with disabilities in statewide mathematics assessments was similar to their participation in reading assessments.
} 
Figure 1: Distribution of State and the District of Columbia Participation Rates on Statewide Reading Assessments in the 2003-04 School Year

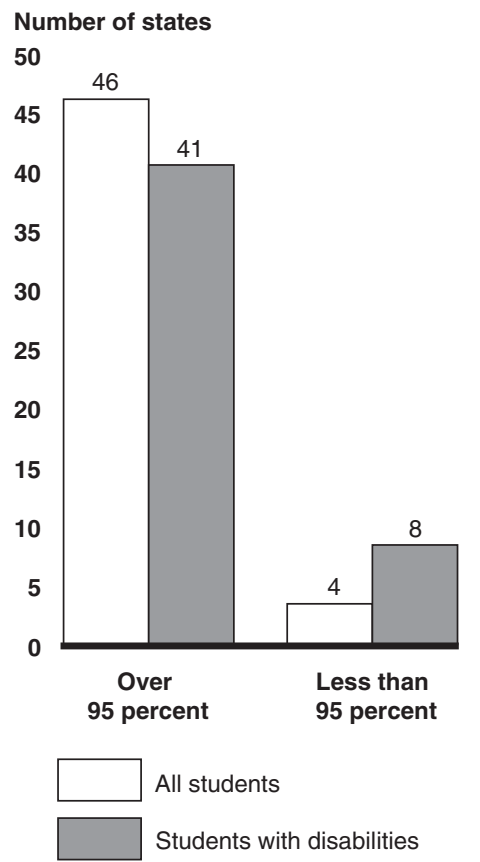

Source: State data reported to Education in consolidated reports.

Note: Two states did not provide data on students with disabilities in a usable format, and one of these states did not provide data for all students in a usable format.

State participation rates for students with disabilities were generally similar to those for all students. Most states reported that an equal or slightly higher percentage of the total student population participated in statewide assessments compared to students with disabilities. Differences in the participation rates were usually minor. Connecticut, Georgia, and Oklahoma reported that the participation rate among students with disabilities in statewide reading assessments was higher than among all students. An official in one state said that the state had made efforts to boost the participation rate of students with disabilities, including issuing state guidance and holding regional workshops. The official also said that, because students with disabilities are a small subset of the state's student population, it is easier to boost participation among students with disabilities than among all students. Participation rate data by state can be found in appendix I. 


\section{Most Students with Disabilities Were Included in Regular Reading Assessments, and Relatively Few Were Included through Alternate Assessments}

In 49 states and the District of Columbia, most students with disabilities who were tested in the 2003-04 school year were included through regular reading assessments. In over two-thirds of these states, more than 90 percent of students with disabilities were included in the regular reading assessment. In the four site-visit states, most students with disabilities were included in the regular reading assessment.

In three of the four site-visit states, the majority of students with disabilities who were included through regular reading assessments received accommodations in the 2003-04 year. These data ranged from 58 percent in Florida to 89 percent in Massachusetts. Data from one state that we visited, Florida, showed that additional time and other scheduling changes and changes of setting were the most frequent accommodations. Although the other 2 states did not provide data on the most frequently used accommodations, small group settings and extended time were the most frequent accommodations on the NAEP reading assessment which reflects the accommodations students receive in statewide assessment systems.

Alternate reading assessments with grade-level standards were used by nine states. In six of these states, less than 10 percent of students with disabilities were included in these assessments. In the other three states, 14 percent to 21 percent of students with disabilities were included in these assessments. Two of the four states that we visited, Massachusetts and Oregon, reported including students with disabilities in alternate reading assessments that measured grade-level standards. For information about the percentage of students included in this type of assessment, see figure 2. For state-by-state use of different types of assessments, see appendix I.

Alternate reading assessments with below grade-level standards were used by 49 states and the District of Columbia. In most of these states less than 10 percent of students with disabilities were included in these assessments. However, Texas included 60 percent of students with disabilities in alternate assessments that measured below grade-level 
standards. ${ }^{9}$ Officials in Hawaii, the only state that did not include any students in this type of assessment, reported that the state is developing an alternate assessment that measures below grade-level standards. All four states that we visited reported including students with disabilities in these assessments. For information about the percentage of students included in this type of assessment, see figure 2.

\footnotetext{
${ }^{9}$ During a January 2005 monitoring visit, Education found that Texas included students in these assessments in a manner that was inconsistent with NCLBA regulations. Texas administered alternate assessments to students with disabilities who were performing below grade level, whether or not the student was significantly cognitively disabled.

Education found that, although Texas alternate assessments measure content that is below grade level, the state has not developed standards for these assessments. Education also found that Texas allowed districts to exceed the 1 percent limit on students with disabilities who could be counted as having met state achievement goals with these assessments.
} 
Figure 2: Distribution of States and the District of Columbia by the Percentages of Students with Disabilities Who Received Alternate Assessments Measuring GradeLevel and Below Grade-Level Standards in the 2003-04 School Year

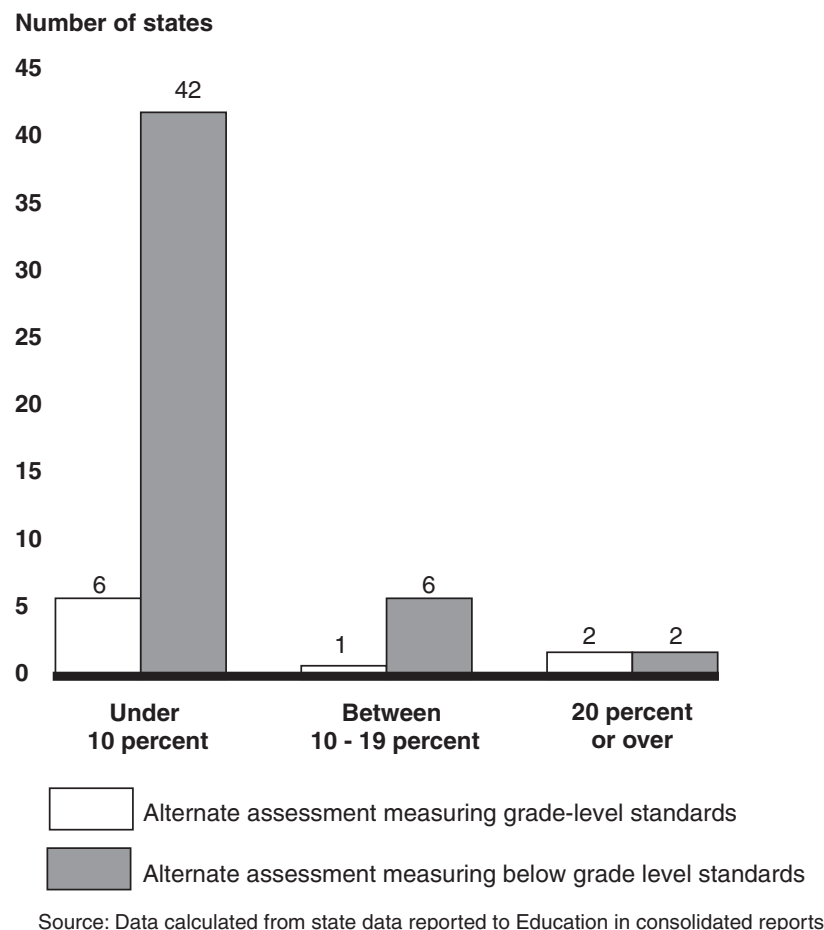

Note: Forty-nine states and the District of Columbia offered alternate reading assessments that measured below grade-level standards and nine states offered alternate assessments that measured grade-level standards. Only these states are included in this figure. Mississippi's alternate assessment measuring alternate standards was included in the 10-19 category.

We examined data in Florida and Massachusetts to determine the relationship between the disability and type of assessment used..$^{10}$ About 40 percent of autistic students received alternate assessments in Massachusetts, the highest of any type of disability. Students with physical disabilities had the highest percentage of students receiving regular assessments without accommodations in Massachusetts. In Florida, over 60 percent of students with autism received alternate assessments measuring below grade-level standards. Table 2 shows assessment data based on disability type for Massachusetts.

\footnotetext{
${ }^{10}$ These data were not available for the other states we visited and were not available nationally.
} 
Table 2: Massachusetts' Data on How Students with Different Types of Disabilities Were Included in Statewide Reading Assessments in the 2003-04 School Year

\begin{tabular}{|c|c|c|c|c|}
\hline \multirow[b]{2}{*}{ Disability Type } & \multicolumn{4}{|c|}{ English/Language arts (tested in grades $3,4,7,10$ ) } \\
\hline & Enrollment & Regular assessment & $\begin{array}{r}\text { Regular } \\
\text { assessment with } \\
\text { accommodations }\end{array}$ & $\begin{array}{r}\text { Alternate assessment } \\
\text { at grade level or } \\
\text { below grade level }\end{array}$ \\
\hline Intellectual & 4,046 & $4 \%$ & $66 \%$ & $28 \%$ \\
\hline Sensory/Hearing & 327 & $10 \%$ & $81 \%$ & $8 \%$ \\
\hline Communication & 5,659 & $21 \%$ & $77 \%$ & $1 \%$ \\
\hline Sensory/Vision & 135 & $12 \%$ & $78 \%$ & $10 \%$ \\
\hline Emotional & 4,126 & $10 \%$ & $85 \%$ & $2 \%$ \\
\hline Physical & 310 & $33 \%$ & $58 \%$ & $8 \%$ \\
\hline Health & 2,145 & $10 \%$ & $88 \%$ & $1 \%$ \\
\hline Specific learning & 24,979 & $9 \%$ & $90 \%$ & $1 \%$ \\
\hline Sensory/Deaf-Blindness & 102 & $6 \%$ & $68 \%$ & $25 \%$ \\
\hline Multiple disabilities & 1,504 & $6 \%$ & $61 \%$ & $31 \%$ \\
\hline Autism & 1,272 & $6 \%$ & $53 \%$ & $40 \%$ \\
\hline Neurological & 1,513 & $11 \%$ & $83 \%$ & $5 \%$ \\
\hline Developmental delay & 1,648 & $13 \%$ & $76 \%$ & $10 \%$ \\
\hline
\end{tabular}

Source: Massachusetts Department of Education.

Note: Massachusetts data did not show whether the alternate assessments measured grade-level or below grade-level standards. Very few students in the state received alternate assessments that measured grade-level achievement standards.

Few differences existed in how students were included in assessments based on their year in school according to data from the two states we visited that provided data. In both Massachusetts and Iowa, a similar percentage of students were given accommodations and alternate assessments across several different grade levels.

Massachusetts and Oregon Used Innovative Approaches to Assess the Performance of Students with Disabilities
Two of the four states that we visited, Massachusetts and Oregon, used what experts described as innovative assessment approaches to measure the performance of students with disabilities. Massachusetts developed an alternate assessment system that can measure grade-level and below grade-level standards. State officials have developed a resource guide that details the alignment between the curriculum and achievement standards. For each content area, the state has identified a progression of increasingly rigorous standards, with grade-level standards as the most rigorous, through which students can demonstrate knowledge of the same content. The performance of all students is measured with the same 
content, but the progression of standards let students with widely varying abilities demonstrate their understanding of the content.

Figure 3: Example of How a Below Grade-Level Standard Differs in Complexity from a Grade-Level Standard

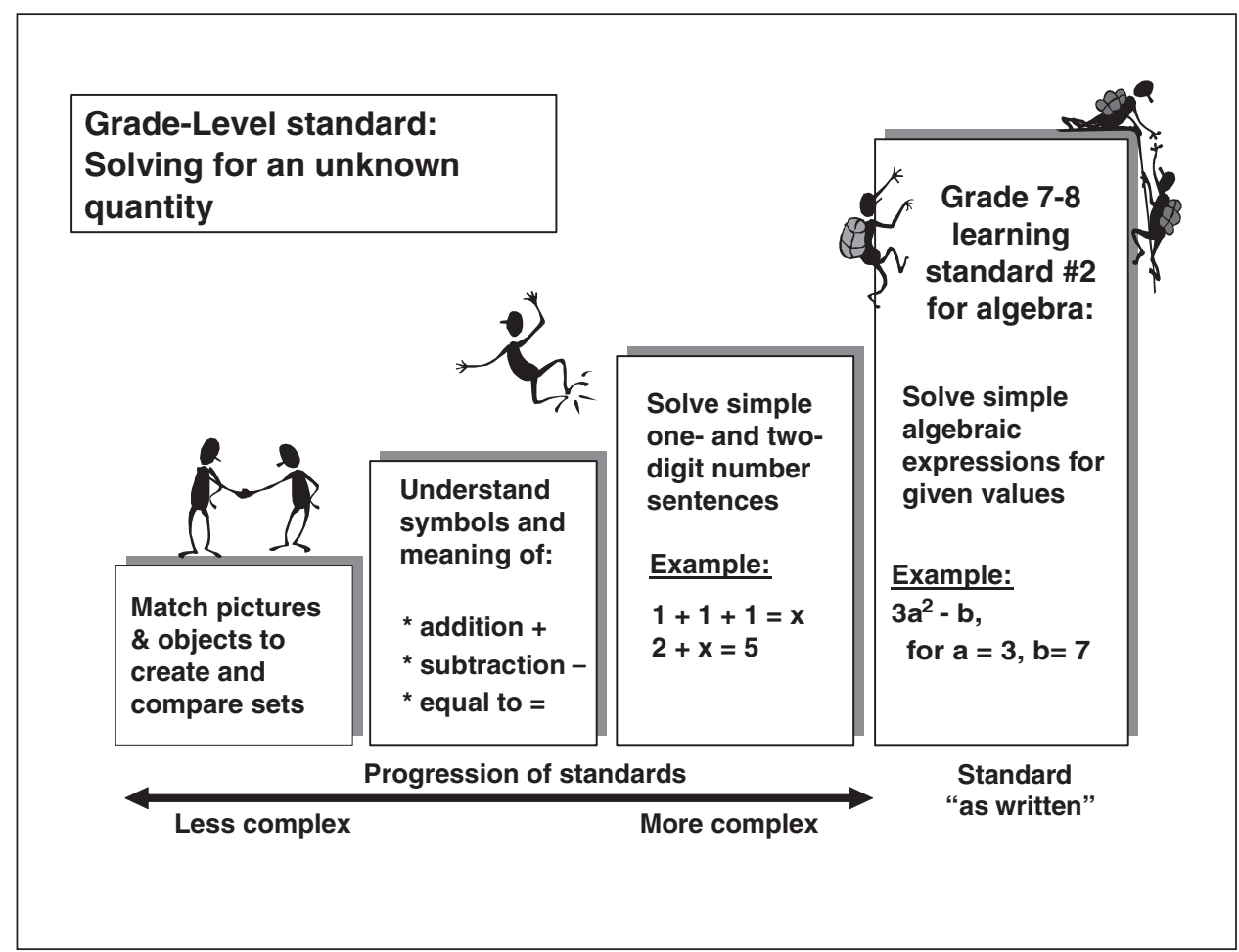

Source: Massachusetts Department of Education.

Oregon's assessment allows all students, disabled and nondisabled, to use certain accommodations when taking the regular assessment. This is considered innovative because it recognizes that any student may need accommodations, regardless of whether they have recognized disabilities, and offers them certain accommodations, such as changes in test settings or timing. In this way, students with and without disabilities are not considered differently in their use of accommodations. 
Nationwide 5 Percent of Students with Disabilities Are Excluded from NAEP, but State Exclusion Rates Varied
The NAEP began offering students with disabilities accommodations in 1996 , and some of the more commonly used accommodations included extended time to complete the assessment, testing in small-group sessions, and reading the directions aloud. Other accommodations included, for example, explanation of directions, scribes, large print, and the use of word processors or similar devices.

NAEP has provided some accommodations, but nationwide about 5 percent of students with disabilities have been excluded from the assessment. Education officials discussed several reasons students with disabilities were excluded from the assessment including: (1) the student had such a severe disability that the student could not meaningfully participate; (2) the principal and the IEP team decided that the student should not participate; and (3) the student's IEP required that the student be tested with accommodations that NAEP does not allow. At the state level, the percentage of students with disabilities who were excluded varied in 2002. For example, over 10 percent of students with disabilities were excluded from the 2002 NAEP reading assessment in three states, and only 2 percent to 3 percent of students with disabilities were excluded in a handful of other states. According to Education officials, the inclusion of students with disabilities in the NAEP assessments is affected by sampling issues as well as by the limitations of accommodations that are appropriate for the content covered by the NAEP.

Research suggests that NAEP results for some states may be affected by exclusion rates. A 2003 report commissioned by Education found that different state exclusion rates affected NAEP's rankings of states on student reading achievement. One purpose of the NAEP is to provide a basis for comparing states, each of which has its own standards and assessment system. These state rankings are often used by states and other organizations to compare states and determine how well states are educating their students. Additionally, state rankings are viewed by parents and state and local officials as important indicators of the quality of their states' education systems. The report examined how state rankings would change under two different assumptions about how excluded students would have performed on the assessment if they had been included. The report found that state rankings changed for over half of the states on both the fourth and eighth grade NAEP with both 
assumptions. In one scenario, two states fell 6 places and one state fell 7 places in the state rankings. ${ }^{11}$

In addition, a 2003 report that was commissioned by the National Assessment Governing Board, an independent, bipartisan body appointed by Education, concluded that changes in state achievement on the NAEP between 1998 and 2002 could be partially explained by changes in exclusion rates. Changes in state results on the NAEP are frequently used by states and researchers to gauge which states have successfully raised student achievement. The study examined the 36 states that participated in both the 1998 and 2002 NAEP reading assessments. The report concluded that "a substantial portion of variation in states' achievement score changes can be accounted for by changes in their rates of exclusion. ${ }^{12} \mathrm{~A}$ report released by Education, the 2002 NAEP Report Card, found similar associations and said that there is a moderate tendency for exclusion rates to be associated with achievement gains but that exclusion rates do not entirely explain score gains. ${ }^{13}$

Some students with disabilities are excluded from the NAEP because it does not allow some accommodations that are permitted by on statewide assessments. Education officials said that certain accommodations would interfere with the NAEP's measurement of the knowledge being assessed. For instance, in the reading assessment, reading the passage and questions aloud to a student was not permitted because the assessment is intended to measure the student's ability to read the written word as well as understand the meaning of the passage. Education officials also said that some accommodations could not be administered with the assessment for logistical reasons. For example, extending testing over several days was

\footnotetext{
${ }^{11}$ For more information, see Statistical Methods to Account for Excluded Students in NAEP at nces.ed.gov/nationsreportcard/pdf/main2002/statmeth.pdf.

${ }^{12}$ This report examined the exclusion of students with disabilities and students with limited English proficiency together and did not address the impact of the exclusion of students with disabilities separately. On the 2002 NAEP reading assessment, about 1.5 times as many students were identified as having disabilities as limited English proficiency. Students with disabilities were more than twice as likely to be excluded as students with limited English proficiency. For more information, see Edward Haertel, Including Students with Disabilities and English Language Learners in NAEP: Effects of Differential Inclusion Rates on Accuracy and Interpretability of Findings (Washington, D.C.: National Assessment Governing Board, December 2003). www.nagb.org/pubs/conferences/haertle.pdf.

${ }^{13}$ For more information, see National Assessment of Educational Progress, Washington, D.C. http://nces.ed.gov/nationsreportcard/pdf/main2002/2003521b.pdf.
} 
not allowed because NAEP testing administrators are in each school only one day. Education has not developed alternate assessments for the NAEP. Table 3 lists accommodations that are allowed on some statewide assessments but not on the NAEP.

Table 3: Accommodations Provided in Some Regular Statewide Assessments but Not for NAEP

\begin{tabular}{l}
\hline Braille edition of assessment $^{\mathrm{a}}$ \\
\hline Audio tape administration of assessment \\
\hline Calculator \\
\hline Abacus \\
\hline Arithmetic tables \\
\hline Graph paper \\
\hline Responses in native primary language \\
\hline Thesaurus \\
\hline Spelling and grammar checking software and devices \\
\hline Signing directions or answers \\
\hline Extending sessions over multiple days
\end{tabular}

Source: National Center for Education Statistics and interviews with Education officials.

Note: See National Center for Education Statistics, NAEP Inclusion Policy, http://nces.ed.gov/nationsreportcard/about/inclusion.asp (June 3, 2005)

${ }^{a}$ The NAEP does not provide a Braille edition of the assessment but does allow states to provide a Braille edition at their own expense.

Another reason why states' exclusion rates for could vary on NAEP may relate to state policies and requirements regarding student participation of students with disabilities. Although states are required to participate in the NAEP, student participation in this assessment is voluntary. Whether students with disabilities take the NAEP depends primarily on the recommendation of the student's IEP team, along with the availability of appropriate accommodations. Team decision criteria could vary across states, leading to differences in exclusion rates.

Education officials said they are implementing a new policy for how students with disabilities should be included in the NAEP assessment that will reduce variability in the inclusion of students with disabilities. Previously, the student's IEP team and principal had to decide whether a student could participate in the NAEP assessment, leaving room for interpretation. The new policy will require schools to include students in the NAEP assessment if the students took the regular statewide 
assessments (with or without accommodations) and the students' IEPs do not specify that they be provided accommodations that NAEP does not allow. In addition, the new policy will require schools to include students with disabilities who took the state's alternate assessment, if the school believes that the students can participate meaningfully in the NAEP assessment. The new policy will first be used with the 2006 NAEP assessments.

States Faced

Challenges in

Designing and

Preparing Teachers to

Administer Alternate Assessments
States faced challenges in designing alternate assessments (for grade- and below grade-level standards) and helping teachers to administer them for this small group of students with widely varying abilities. Officials from the four states we studied in depth, assessment companies, and national education organizations told us that designing and implementing alternate assessments that measured student achievement on state standards was difficult. These officials also told us that special education teachers needed training over a period of up to 3 years to administer alternate assessments properly.

\section{National Education Organizations and Some State Officials Reported Difficulties Designing Alternate Assessments}

Widely Varying Abilities of Students with Disabilities
Designing alternate assessments posed difficulties, in part because of states' inexperience with these types of assessments. Education officials and representatives from national education organizations told us that many states did not begin to design alternate assessments until required to do so by IDEA 1997 for the 2000-01 school year. Education officials noted that states' alternate assessments generally had not been aligned to state standards. Specifically, many states designed their alternate assessments to measure functional skills, such as using public transportation independently, rather than academic achievement. Consequently, designing alternate assessments that measured academic achievement was relatively new for many states. ${ }^{14}$

The widely varying abilities of students was identified by experts and officials as a key factor that made designing alternate assessments to measure academic achievement challenging. For example, some students with significant cognitive disabilities can communicate verbally or through using technology such as boards with pictures to which the student can point, while others can communicate only through moving their eyes or

\footnotetext{
${ }^{14}$ Alternate assessments under NCLBA were first discussed as part of Education's standards and assessment regulations. These final regulations were issued on July 5, 2002. Alternate assessments were also discussed in regulations issued on December 9, 2003.
} 
blinking. Further, some students may best show their achievement through working with their teacher, while others have the ability to create work samples independently. Still other students may be able to take portions of the regular assessment in one subject, but require a different approach for another subject. National assessment and education experts told us that measuring these students' achievement often required an individualized approach.

\section{Design Process Took Time}

Efforts to design alternate assessments that measured academic achievement as required by NCLBA took about 3 years, according to federal education officials and assessment experts. The process for designing alternate assessments involved a number of steps and decisions, such as choosing a format and revising or modifying assessments. In the four states we studied, two offered the portfolio format as their alternate assessment, and the other two offered a number of options, including the portfolio. See table 4 for a description of these assessments.

\section{Table 4. Selected Alternate Assessments Used in Study States and Descriptions}

\begin{tabular}{lll}
\hline Alternate assessments & Achievement standard & Description \\
\hline Portfolio & $\begin{array}{l}\text { Grade-Level or below } \\
\text { grade-level achievement }\end{array}$ & $\begin{array}{l}\text { A collection of student work gathered to demonstrate student } \\
\text { performance on specific skills and knowledge, generally linked to state } \\
\text { content standards. Portfolio contents are individualized and may } \\
\text { include, among other evidence, samples of student work, test results, } \\
\text { and video records of student performance. }\end{array}$ \\
\hline Performance assessment & $\begin{array}{l}\text { Grade-Level or below } \\
\text { grade-level achievement }\end{array}$ & $\begin{array}{l}\text { A direct measure of student skills or knowledge, usually in a one-on-one } \\
\text { assessment. These can be highly structured, requiring a teacher or } \\
\text { assessment administrator to give students specific items or tasks, } \\
\text { similar to regular assessments or based on student needs. }\end{array}$ \\
\hline Out of level assessment & $\begin{array}{l}\text { Below grade-level } \\
\text { achievement }\end{array}$ & A regular assessment for a lower grade level.
\end{tabular}

Source: National Center on Educational Outcomes.

Creating alignment between these assessments and the curriculum and achievement standards, as required by NCLBA, was challenging and labor intensive, according to officials in our study states, representatives from national education organizations, and assessment experts. Specifically, the curriculum should include subject matter outlined in the achievement standards, and the alternate assessment should properly determine whether students have mastered the standards. For example, if the standard were to understand written English, the curriculum might include reading and understanding grade-level text. An alternate assessment with below grade-level standards might include a student reading one- or two-word items and matching them to familiar people, 
Individualized and

Standardized Assessments and Reliability of Assessments places, or things. Because states generally had not designed alternate assessments nor assessed students with disabilities on academic achievement before 2000, aligning standards with alternate assessments was relatively new. Further, alignment was difficult because of the need to provide a way for students with widely varying abilities to display their achievement.

Further, officials explained that it can be difficult to reconcile the need to administer individualized assessments under IDEA and the need to provide standardized assessments under NCLBA for these students. These concerns were also reflected in a recent report on NCLBA from a national education organization. ${ }^{15}$ Specifically, standardized alternate assessments may not be appropriate for all students who need an alternate assessment because they may not be flexible enough to accommodate all students' abilities. However, experts and officials noted that individualized assessments, such as portfolios, can also present challenges. For example, because individualized assessment approaches often rely heavily on the participation of the person administering the assessment, that person can affect how students demonstrate their performance. Teachers may select work samples that demonstrate exceptional performance of their student, even though the student does not typically perform that well.

Officials in one state told us that a team of education officials determined that their alternate assessment needed to be more reliable in both implementation and scoring, a sentiment shared by officials and teachers in other states as well. Scoring in the states we studied was done by the student's teacher, teachers from other districts, or officials from the local education agency. Officials in the state in which teachers score their own students said that no independent reviews determined whether the scores were accurate or unbiased, and teachers from two other states told us that scores for similar portfolios sometimes varied.

A number of states used advisory committees to help them design their alternate assessments, according to assessment experts and state officials. These committees can be composed of experts in the field of assessment, and they provide guidance to state officials. For example, officials in one state told us that a series of three advisory committees helped them make

\footnotetext{
${ }^{15}$ Center on Education Policy, From the Capital to the Classroom: Year Three of the No Child Left Behind Act (Washington, D.C.: March 2005). http://www.ctredpol.org/pubs/nclby3/.
} 
decisions about their alternate assessment, including its format. Officials in another state told us that they met with a working group for 2 years in preparation for assessing students with disabilities on alternate assessments. Information reported by officials in all states to Education for the 2003-4 school year indicated that many states are currently revising or modifying their alternate assessments.

Officials in two of the four states also reported that they were not using alternate assessments based on grade-level standards because they were unaware of models that appropriately measured achievement. National assessment and education experts said that education officials from many states had expressed similar views. In two of the four states we studied not using these assessments, some local officials told us that they would like to use this assessment option.

Finally, assessment experts and state officials told us that designing and implementing these assessments was costly for this small group of students. They also said that there were start-up costs in addition to the annual cost for implementation. For example, officials in one state we studied estimated that they spent approximately $\$ 591,000$ in the first year of implementation. These costs included designing the assessment, training teachers to administer the assessments and training scorers to score the assessments. These officials told us that costs have decreased to approximately $\$ 164,000$ in the third year of implementation. Assessment experts estimated that the annual cost for alternate assessments per student ranged from $\$ 75$ to $\$ 400$, compared with $\$ 5$ to $\$ 20$ for regular assessments. A prior GAO report ${ }^{16}$ similarly associated lower costs with assessments scored by machine-a paper and pencil test with answers marked on a bubble sheet-and greater costs for assessments scored by people, as alternate assessments often are.

Extensive Training and Implementation Posed Challenge for Teachers
Teachers responsible for administering alternate assessments needed training on the use, administration, and scoring of these assessmentswhich could take 2 years to 3 years plus some ongoing training-according to federal and state officials, as well as education and assessment experts. Assessing students with disabilities was a relatively new role for veteran teachers and different from overseeing a classroom of students for regular

\footnotetext{
${ }^{16}$ GAO, Title I: Characteristics of Tests Will Influence Expenses; Information Sharing May Help States Realize Efficiencies, GAO-03-389 (Washington, D.C.: May 8, 2003).
} 
assessments during class time. In addition, new teachers needed additional training because they had limited course work on assessment issues in their teacher preparation programs. Assessment experts and officials in the states we studied told us that these programs generally provided one course in assessment, but that the course did not provide enough training in how to administer alternate assessments, interpret results, or use results to improve their instruction. Teachers needed to become familiar with these assessments, including portfolio assessments, which may involve many hours of creating, compiling, and documenting samples of student work both during and outside of class. ${ }^{17}$ Further, some ongoing refresher training was needed, particularly when alternate assessments were modified from year to year and when teachers did not administer alternate assessments every year.

Special education teachers also needed to learn the regular academic curriculum and state standards upon which alternate assessments are based. Historically, special education teachers had little exposure to this curriculum and its associated standards because they have taught functional skills, such as shopping independently in stores. Officials in one state told us that their teachers faced a learning curve to become familiar with the academic curriculum and how to create appropriate ways for their students to access that curriculum. For example, the grade-level curriculum might teach students to determine the meaning of unknown words from their context for the fourth grade reading assessment. A special education teacher would need to learn the grade-level curriculum and then match a student's skills with an appropriate task to demonstrate mastery for the student's individual level. For example, a highly functioning special education student might demonstrate mastery by using a dictionary to determine the meaning of unknown words. A student with significant cognitive disabilities might demonstrate mastery by associating a picture with a familiar object, action, or event.

Finally, despite the challenges of implementing alternate assessments, teachers and state officials shared success stories for students with

\footnotetext{
${ }^{17}$ For example, portfolios in one state required three work samples, including a sheet on which the teacher tracked student performance during the school year, for each of five content areas for each subject assessed. For a student taking an alternate assessment in reading and math, two separate portfolios with fifteen work samples each would need to be created. Veteran teachers in one state emphasized the need to collect work samples as part of their everyday teaching activities. Although it was challenging to incorporate the practice into their classrooms, this made assembling the portfolios much easier and faster.
} 
disabilities. For example, officials who developed a guide matching gradelevel and below grade-level standards told us that this investment was worthwhile because it helped teachers become better teachers by identifying a progression of standards for students with disabilities to access grade-level academic curriculum. In addition, officials in some states noted that it was valuable that special education teachers were encouraged to teach academic curriculum to students with significant cognitive disabilities under NCLBA. Teachers told us many stories of student achievement, which exceeded their expectations. For example, one teacher described teaching the difference between sweet and sour to a student with severe and multiple disabilities. The student, after tasting both, consistently signaled "sweet" by looking toward the sweet item repeatedly when asked which she preferred. Experts, officials and teachers were generally positive about raising academic expectations for students with disabilities and attributed this directly to NCLBA.

Education Disseminated Information to States on Assessing Students with Disabilities, but Some State Officials Reported the Need for Alternate Assessment Examples
Education's efforts to help states implement assessment requirements for students with disabilities included a variety of activities. However, state officials said that additional information, such as examples of alternate assessments, would be helpful. We presented states' concerns to Education in March 2005. Education announced in May 2005 that it was developing guidance and planned to provide comprehensive technical assistance to states on this topic as early as the Fall of 2005. We also found that it was difficult to locate assessment information on Education's Web site because there was no Web link that associated the alternate assessment information on the site's NCLBA section with related information on the research, development, and use of these assessments that is available on other sections of the site. 
Education Provided Many Types of Assistance, but Officials Said Examples of Alternate Assessment Approaches Would Be Helpful
Education provided a broad range of assistance to help states implement assessment requirements for students with disabilities, such as disseminating guidance that included technical information on alternate assessments, reviewing state assessment plans, awarding grants to help states improve their assessment systems, and conducting on-site visits. ${ }^{18}$ Further, Education has conducted outreach efforts to states to communicate the requirements for the inclusion of students with disabilities under NCLBA and to improve state data systems to ensure they capture the true achievement and participation of students in these assessments. For example, the department's Office of Special Education Program' Regional Resource Centers and other technical assistance projects have collaborated with states through teleconferences, preconference training sessions, and by providing technical assistance materials and resources. Education also made extensive use of its NCLBA Web site, newsletters, and attendance at national education-related conferences to disseminate guidance to states on NCLBA's assessment requirements for all students, including students with disabilities.

The department also funded two national centers that had, as part of their focus, the assessment of students with disabilities - the National Center on Educational Outcomes and the National Alternate Assessment Center. The National Center on Educational Outcomes examined the participation of students in national and statewide assessments, including the use of accommodations and alternate assessments and conducted research in the area of assessment and accountability. In addition, the National Alternate Assessment Center established principles of technical soundness for alternate assessments and techniques for aligning alternate assessments with grade-level content standards.

Despite Education's efforts to assist states in this area, experts and some state officials identified challenges in designing and implementing alternate assessments. As noted above, many states had limited experience with these assessments. Representatives from a national education organization and officials in two of the four study states, specifically the two states not using these assessments, said that they did not know how alternate assessments that measured grade-level standards would look, and that examples would be helpful. Further, only nine states

\footnotetext{
${ }^{18}$ According to Education officials, this assistance was provided primarily through the Office of Elementary and Secondary Education and the Office of Special Education Programs, with support from the Institute of Education Sciences and the Office for Civil Rights.
} 
reported using these assessments in the 2003-04 school year. According to Education officials, the department has made information on alternate assessments available during preconference workshops at national education-related conferences and through the National Center on Educational Outcomes' Web site. Education officials also reported that the department participated with state officials in a group including state officials and national education experts that discussed and researched alternate assessments. However, information provided to state officials often included brief descriptions of alternate assessments but not illustrative examples to help states. In March 2005, we told Education about states' alternate assessment concerns. In May 2005, Education announced additional efforts to help states use alternate assessments. Under these efforts, which are being conducted by a department task force and funded by $\$ 5$ million from the department's Office of Special Education and Rehabilitative Services, Education plans to provide comprehensive technical assistance to states that lack alternate assessment plans as early as the fall of 2005. According to Education officials, plans for providing assistance to states in this area were still being developed. As a result, we were unable to review Education's plans, and the extent to which the department's efforts will address states' concerns about alternate assessments is unknown.

Information on Assessment of Students with Disabilities Not Easily Located on Education's Web Site
According to Education officials, information concerning the inclusion of students with disabilities in statewide assessments has been primarily disseminated through the department's Web site. Our review of Education's Web site, however, disclosed that certain information on the development and use of alternate assessment for students with disabilities was difficult to locate. For example, the NCLBA section of Education's Web site provided extensive information about the regulatory requirements for alternate assessments. However, information on the research, development, and use of these assessments was generally accessed through a series of non-assessment-related Internet links on the Office of Special Education Programs (OSEP) section of Education's Web site. Moreover, there was no Web link that associated the alternate assessment information on the NCLBA section of the Web site with related information on the OSEP section of the Web site. In addition, accessing alternate assessment information on the OSEP Web site was complicated because it required the user to have a working knowledge of OSEP's programs, knowledge that some statewide assessment officials may not have. 


\section{Conclusions}

NCLBA seeks to make fundamental changes in public education by challenging federal, state, and local education officials to improve student performance. In particular, NCLBA focused attention on the academic performance of all students, requiring that the performance of groups, such as students with disabilities, be considered in determining whether schools meet state goals. IDEA has also emphasized the importance of assessing the academic achievement of students with disabilities. Education has provided much guidance to states on how to include students with disabilities in statewide assessment systems. Despite their efforts, some state and local officials as well as national organization representatives reported they lacked alternate assessment examples or models, particularly at grade-level standards, and were uncertain about how to design and implement them. This uncertainty may have contributed to some states not using alternate assessments with gradelevel standards. As a result, some students with disabilities may not have been provided the most appropriate type of assessment to measure their achievement. In May 2005, Education announced additional efforts to help states use alternate assessments. According to Education officials, plans for providing assistance to states in this area were still being developed. As a result, we were unable to review Education's plans, and the extent to which the department's effort will address states' concerns about alternate assessments is unknown.

Given that Education has relied heavily on its Web site to provide information on assessing children with disabilities and our finding that this information was not very accessible, the effectiveness of this communication may be limited. As a result, state and local officials may not have all the necessary information available to guide decisions about appropriately including students with disabilities in statewide assessments.

Finally, NCLBA requires that students, including those with disabilities, periodically participate in the NAEP to gain a national picture of student achievement. Although most students with disabilities participated in the NAEP, the percent of students who were excluded from the assessment varied across the states. Consequently, the results of this assessment may not fully reflect student achievement, thus comparisons of student achievement across states may have limitations. 
Recommendations for Executive Action
We recommend that the Secretary of Education take the following two actions to increase the participation of students with disabilities in assessments.

We recommend that the Secretary of Education explore ways to make the information on the inclusion of students with disabilities in statewide assessments more accessible to users of its Web site. Specifically, information on the NCLBA section of Education's Web site concerning alternate assessment requirements for students with disabilities should be linked to information on the research, development, and use of these assessments that is available on other sections of Education's Web site.

Finally, we recommend that the Secretary of Education work with states, particularly those with high exclusion rates, to explore strategies to reduce the number of students with disabilities who are excluded from the NAEP assessment.
Agency Comments and Our Evaluation
We provided a draft of this report to Education for review and comment. In their letter, Education officials noted that they were taking actions that would address the recommendations in this report. For example, in response to the first recommendation, the department will explore the use of "hot buttons" and links among the Web pages maintained by different Education offices to further increase access to information regarding the assessment of students with disabilities. Similarly, in response to the second recommendation, Education officials acknowledged that there is still much work to be done in increasing the participation and inclusion rates of students with disabilities in the NAEP assessment. As part of this effort, the department is exploring strategies for enhancing the inclusion of students with disabilities in the NAEP assessment.

We have also included some additional information the department provided to us on outreach and technical assistance efforts on the assessment of students with disabilities and how students with disabilities participated in the NAEP. Education officials also provided technical comments that we incorporated into the report where appropriate. Education's written comments are reproduced in appendix II.

Copies of this report are being sent to the Secretary of Education, relevant congressional committees, and other interested parties. We will also make copies available to others upon request. In addition, the report will be made available at no charge on GAO's Web site at http://www.gao.gov. 
If you or your staff have any questions about this report, please contact me on (202)512-7215 or at shaulm@gao.gov. Contact points for our Offices of Congressional Relations and Public Affairs may be found on the last page of this report. Other contacts and major contributors are listed in appendix III.

Sincerely yours,

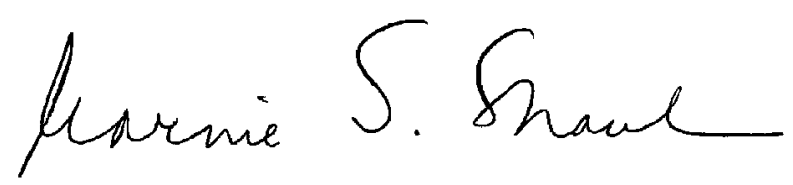

Marnie S. Shaul

Director, Education, Workforce, and Income Security Issues 


\section{Appendix I: Percent of Students with Disabilities Participating in State Reading/Language Arts Assessments in the 2003-04 School Year, by State}

\begin{tabular}{|c|c|c|c|c|c|c|}
\hline & $\begin{array}{r}\text { Percent of total } \\
\text { student } \\
\text { population } \\
\text { participating in } \\
\text { reading exams }\end{array}$ & $\begin{array}{r}\text { Percent of } \\
\text { students with } \\
\text { disabilities } \\
\text { participating in } \\
\text { reading exams }\end{array}$ & $\begin{array}{r}\text { Percent of } \\
\text { students with } \\
\text { disabilities } \\
\text { tested who } \\
\text { participated in } \\
\text { regular reading } \\
\text { assessments }\end{array}$ & $\begin{array}{r}\text { Percent of } \\
\text { students with } \\
\text { disabilities } \\
\text { tested who } \\
\text { participated in } \\
\text { alternate reading } \\
\text { assessments } \\
\text { measuring } \\
\text { grade-level } \\
\text { standards }\end{array}$ & $\begin{array}{r}\text { Percent of } \\
\text { students with } \\
\text { disabilities } \\
\text { tested who } \\
\text { participated in } \\
\text { alternate reading } \\
\text { assessments } \\
\text { measuring below } \\
\text { grade-level } \\
\text { standards }^{a}\end{array}$ & $\begin{array}{c}\text { Percent of data } \\
\text { on participation } \\
\text { by assessment } \\
\text { type that was } \\
\text { unreported or } \\
\text { missing }\end{array}$ \\
\hline Alabama & 94.6 & 86 & 76 & 0 & 6 & 18 \\
\hline Alaska & 98 & 97 & 96 & 0 & 4 & 0 \\
\hline Arizona & 100 & 96 & 91 & 0 & 9 & 0 \\
\hline Arkansas & 97 & 90 & 93 & 0 & 7 & 0 \\
\hline California & 98 & 98 & 92 & 0 & 8 & 0 \\
\hline Colorado & 100 & 100 & 91 & 0 & 7 & 2 \\
\hline Connecticut & 96 & 98 & 82 & 0 & 18 & 0 \\
\hline Delaware & 99 & 98 & 93 & 0 & 7 & 0 \\
\hline $\begin{array}{l}\text { District of } \\
\text { Columbia }\end{array}$ & 93 & 86 & 94 & 0 & 6 & 0 \\
\hline Florida & $98^{b}$ & $96^{b}$ & 88 & 0 & 12 & 0 \\
\hline Georgia & 92.9 & 93 & 94 & 0 & 6 & 0 \\
\hline Hawaii & 98 & 96 & 97 & 3 & 0 & 0 \\
\hline Idaho & 99 & 99 & 94 & 0 & 4 & 2 \\
\hline Illinois & 99 & 98 & 94 & 0 & 6 & 0 \\
\hline Indiana & 100 & ${ }^{c}$ & 95 & 0 & 5 & 0 \\
\hline lowa & 99 & 98 & 96 & 0 & 4 & 0 \\
\hline Kansas & 99 & 98 & 73 & 21 & 6 & 0 \\
\hline Kentucky & 99 & 99 & 93 & 0 & 7 & 0 \\
\hline Louisiana & 100 & $99^{a}$ & 83 & 0 & 17 & 0 \\
\hline Maine & 100 & 99 & 93 & 0 & 7 & 0 \\
\hline Maryland & 100 & 100 & 91 & 0 & 9 & 0 \\
\hline Massachusetts & 100 & 99 & 94 & $<1$ & 6 & 0 \\
\hline Michigan & ${ }^{\circ}$ & ${ }^{\circ}$ & 65 & 0 & 35 & 0 \\
\hline Minnesota & 97 & 95 & 88 & 0 & 12 & 0 \\
\hline Mississippi & 99 & 96 & 89 & 0 & $9-12^{d}$ & 0 \\
\hline Missouri & 99 & 96 & 99 & 0 & 1 & 0 \\
\hline Montana & 100 & 99 & 93 & 0 & 7 & 0 \\
\hline Nebraska & 99 & 96 & 96 & 0 & 4 & 0 \\
\hline
\end{tabular}


Appendix I: Percent of Students with

Disabilities Participating in State

Reading/Language Arts Assessments in the

2003-04 School Year, by State

\begin{tabular}{|c|c|c|c|c|c|c|}
\hline & $\begin{array}{r}\text { Percent of total } \\
\text { student } \\
\text { population } \\
\text { participating in } \\
\text { reading exams }\end{array}$ & $\begin{array}{r}\text { Percent of } \\
\text { students with } \\
\text { disabilities } \\
\text { participating in } \\
\text { reading exams }\end{array}$ & $\begin{array}{r}\text { Percent of } \\
\text { students with } \\
\text { disabilities } \\
\text { tested who } \\
\text { participated in } \\
\text { regular reading } \\
\text { assessments }^{\text {as }}\end{array}$ & $\begin{array}{r}\text { Percent of } \\
\text { students with } \\
\text { disabilities } \\
\text { tested who } \\
\text { participated in } \\
\text { alternate reading } \\
\text { assessments } \\
\text { measuring } \\
\text { grade-level } \\
\text { standards }^{\text {a }}\end{array}$ & $\begin{array}{r}\text { Percent of } \\
\text { students with } \\
\text { disabilities } \\
\text { tested who } \\
\text { participated in } \\
\text { alternate reading } \\
\text { assessments } \\
\text { measuring below } \\
\text { grade-level } \\
\text { standards }^{\text {a }}\end{array}$ & $\begin{array}{c}\text { Percent of data } \\
\text { on participation } \\
\text { by assessment } \\
\text { type that was } \\
\text { unreported or } \\
\text { missing }\end{array}$ \\
\hline Nevada & $98^{a}$ & 97 & 97 & 0 & 3 & 0 \\
\hline New Hampshire & 99 & 99 & 95 & 0 & 5 & 0 \\
\hline New Jersey & 99 & 97 & 95 & 0 & 5 & 0 \\
\hline New Mexico & $97^{a}$ & $94^{a}$ & 95 & 0 & 5 & 0 \\
\hline New York & $98^{a}$ & $93^{a}$ & 89 & 1 & 4 & 6 \\
\hline North Carolina & 100 & 99 & 87 & 9 & 3 & 0 \\
\hline North Dakota & 100 & 98 & 92 & 0 & 8 & 0 \\
\hline Ohio & 98 & 96 & 95 & 0 & 5 & 0 \\
\hline Oklahoma & 99 & 100 & 84 & 0 & 16 & 0 \\
\hline Oregon & 100 & 99 & 76 & 14 & 9 & 0 \\
\hline Pennsylvania & 98 & 94 & 94 & 0 & 6 & 0 \\
\hline Rhode Island & 99 & 98 & 97 & 0 & 3 & 0 \\
\hline South Carolina & 99 & 98 & 88 & 0 & 3 & 9 \\
\hline South Dakota & 99 & 99 & 93 & 0 & 7 & 0 \\
\hline Tennessee & 99 & 99 & 92 & 0 & 8 & 0 \\
\hline Texas & 94.6 & 77 & 39 & 0 & 60 & 1 \\
\hline Utah & 97 & 95 & 93 & $<1$ & 7 & 0 \\
\hline Vermont & 100 & 99 & 74 & 20 & 6 & 0 \\
\hline Virginia & 99 & 97 & 92 & 0 & 8 & 0 \\
\hline Washington & 100 & 100 & 94 & 0 & 6 & 0 \\
\hline West Virginia & 99 & 98 & 96 & 0 & 4 & 0 \\
\hline Wisconsin & 99 & 98 & 91 & $<1$ & 9 & 0 \\
\hline Wyoming $^{e}$ & 100 & 99 & 98 & 0 & 6 & 0 \\
\hline
\end{tabular}

Source: GAO analysis; State consolidated performance reports to Education.

Note: Figures rounded to the nearest whole number, except in cases where rounding would have made numbers appear inconsistent with other sections of the report.

${ }^{a}$ Calculated by GAO from state data.

${ }^{\text {b}}$ Florida does not calculate participation rate separately for reading and for mathematics. The information included in this table is the participation rate for reading and mathematics combined.

'Did not provide usable data

${ }^{\mathrm{d}}$ Mississippi reported a range for this figure. 
Appendix I: Percent of Students with

Disabilities Participating in State

Reading/Language Arts Assessments in the

2003-04 School Year, by State

${ }^{e}$ Sum of the number of students with disabilities participating in the three different types of reading assessments was greater than figure the state provided for the total number of students participating in reading assessments. 


\section{Appendix II: Comments from the Department of Education}

\section{UNITED STATES DEPARTMENT OF EDUCATION}

WASHINGTON, D.C. 20202-

June 30,2005

Ms. Marnie S. Shaul

Director, Education, Workforce

and Income Security Issues

Government Accountability Office

441 G Street, NW

Washington, DC 20548

Dear Ms. Shaul:

We are writing in response to your request for comments on the Government Accountability Office (GAO) draft report (GAO-05-618), dated July 2005, and entitled "No Child Left Behind Act: Most Students with Disabilities Participated in Statewide Assessments, but Inclusion Options Could Be Improved." As the first half of the draft report title indicates, States, school districts and schools have made significant progress in including students with disabilities in State academic assessments and, with the assistance of the U.S. Department of Education (the Department), have developed assessments and accommodations, to ensure that the legal requirements for inclusion of students with disabilities are met. We appreciate the opportunity to comment on the draft report and provide insight on actions the Department is taking to improve the assessment of students with disabilities.

Our nation is giving an unprecedented and high level of attention to the meaningful inclusion of all students with disabilitics in academic achievement assessments. The No Child Left Behind Act (NCLBA) expanded the alternate assessment and assessment accommodations requirements established under the Improving America's Schools Act in 1994, and the Individuals with Disabilities Education Act in 1997. The Department's Title I standards and assessment regulations require that all reading/language arts and mathematics assessments used for accountability, including alternate assessments, meet the same rigorous technical quality, alignment, inclusion, and reporting standards. Because the law now requires inclusion of the test scores of students with disabilities in school, district, and State accountability determinations, States, districts, and schools can no longer exclude students from receiving access to the general curriculum, or from determinations that establish if a school or district is preparing students adequately for their future. With the implementation of NCLBA, we have an assurance that all students' academic performance counts, including students with disabilities.

Regarding the recommendations contained in the draft report, we are providing the following responses: 


\section{Appendix II: Comments from the Department}

of Education

Page 2 - Ms. Marnie S. Shaul

GAO Recommendation 1: The Secretary of Education [should] explore ways to make the information on the inclusion of students with disabilities in statewide assessments more accessible to users of its Web site. Specifically, information on the NCLBA section of Education's Web site concerning alternate assessment requirements for students with disabilities should be linked to information on the research, development, and use of these assessments that is available on other sections of Education's Web site.

Through the Web pages of the Department's various offices -- including the Office for Civil Rights, the Office of Elementary and Secondary Education, and the Office of Special Education and Rehabilitative Services -- the Department's Web site offers helpful information regarding the assessment of students with disabilities. To further increase the public's access to this information, the Department will explore establishing "hot buttons" and links among the Web pages maintained by our different offices. In addition to using the World Wide Web to disseminate information, the Department engages in ongoing outreach efforts to provide direct technical assistance to States. As a result, our nation is seeing the highest level of inclusion of students with disabilities in State academic assessments since inclusion became a statutory requirement.

The Department collaborates extensively with States regarding the inclusion of students with disabilities in the assessments required by NCLBA. The Department's outreach communicates the requirements for student inclusion in the assessments under NCLBA, which have contributed significantly to the increased participation rates cited in the GAO draft report showing that students with disabilities are being included in the academic assessment for most States at levels at or above those targeted by the NCLBA statute. The Department's outreach also includes working with States to improve their data systems to ensure they capture the true achievement and participation of students. For example, the seven States noted with inclusion rates below 95 percent have already begun to address their data management and documentation systems to more accurately report the participation rates for students in the required State academic assessments used for accountability.

The Department's outreach is reflected by participation of our staff in meetings with State directors of special education, assessment and Title I; collaboration with the National Center for Educational Outcomes (NCEO), and the National Alternate Assessment Center (NAAC); and participation in Council of Chief State School Officers' (CCSSO) State collaborative quarterly meetings, which include collaboratives that focus on special education assessment, technical issues in large scale assessment, accountability systems reporting, and comprehensive assessment systems. These State collaboratives include representatives from 49 States, DC, Puerto Rico and several of the outlying areas. The Office of Special Education Programs' (OSEP) Regional Resource Centers and other OSEP technical assistance projects also collaborate with States via teleconferences, preconference training sessions, and by providing technical assistance materials and resources. Additionally, since April 7, 2005, our Web site has included a Plan of Action letter for outreach to States to include students with disabilities who would benefit from the opportunity to be assessed using an assessment instrument that is aligned with a State's academic content standards and with modified academic achievement standards. 
Appendix II: Comments from the Department of Education

Page 3 - Ms. Marnie S. Shaul

While the draft report does not address Department outreach, the inclusion of these activities in the report would provide a more complete picture of our efforts to disseminate reliable information to States.

GAO Recommendation 2: The Secretary of Education [should] work with states, particularly those with high exclusion rates, to explore strategies to reduce the number of students with disabilities who are excluded from the NAEP assessment.

We appreciate GAO's recommendation that the Department work with States to explore strategies to include more students with disabilities in the NAEP assessments. After NCLBA was signed into law, the Department's National Center for Education Statistics contracted with each State educational agency to fund a NAEP coordinator for the State. These coordinators assist with many activities related to the NAEP State assessments, including assistance with briefing State and local educators and parents about NAEP's inclusion and accommodation procedures.

We do need to point out that NAEP cannot include all students with disabilities, although the recommendation could be read to suggest otherwise. For example, NAEP is conducted only in regular graded schools and not in special schools for students with disabilities, such as schools for the blind. In addition, NAEP does not conduct alternate assessments for students whose disabilities are too severe to allow them to take the regular assessments, nor does NAEP permit all of the accommodations that are allowed in some States. For example, NAEP does not permit reading the reading assessment aloud to students with disabilities because NAEP tests a student's ability to read printed English. Your report should thus reflect that NAEP assessments are different from State academic assessments and that the inclusion of students with disabilities in NAEP assessments is affected by sampling issues as well as by the limitations of accommodations that are appropriate for the content covered by NAEP.

Inclusion rates for students with disabilities improved dramatically for NAEP over the last decade, as NCES supported research on the effects of accommodations on test performance and the comparability of assessment results. NAEP now provides a range of accommodations that were not available in earlier assessments. In addition, the variation in exclusion rates among States is declining. More States are including more students with disabilities in NAEP assessments. We expect to see States including even more students with disabilities in the future because of a policy recently adopted by the National Assessment Governing Board (NAGB) with regard to the criteria to be used by schools in determining whether a student should participate in NAEP assessments. Through the 2005 assessments, NAEP policy required that schools include students in NAEP unless the students were too severely cognitively impaired to participate meaningfully in the assessments. This policy permitted individual schools to make the decision about which students should participate in the assessments and led to variability in the inclusion of students across sampled schools. Starting with the 2006 assessments, NAGB's new NAEP policy will require schools to include students in NAEP if the students took the regular State assessments (with or without accommodations) and the students' IEPs do not specify that they must be provided accommodations that NAEP 
Appendix II: Comments from the Department

of Education

Page 4 - Ms. Marnie S. Shaul

does not allow. (The NAGB policy will also require schools to include students with disabilities who took the State's alternate assessment, if the school believes that the students can participate meaningfully in NAEP.)

The Department continues to provide guidance and technical assistance to the few States that are not successful in expanding the inclusion of students with disabilities in their assessments. The Department's Institute of Education Sciences, guided by NAGB, continues to explore strategies for enhancing the inclusion of various underrepresented groups in the NAEP assessments and has been successful in expanding the inclusion of students with disabilities in its State samples. The Department acknowledges that there is still much work to be done in increasing the participation and inclusion rates of students with disabilities from the 95 percent that most States have achieved to 100 percent. We look forward to continuing to work with States as they develop and implement the new assessment systems that are inclusive of all students. The Department will also continue to support States in their efforts to improve data quality and accountability.

We have already provided technical comments on the draft report to your office. Thank you again for the opportunity to comment.

Sincerely,
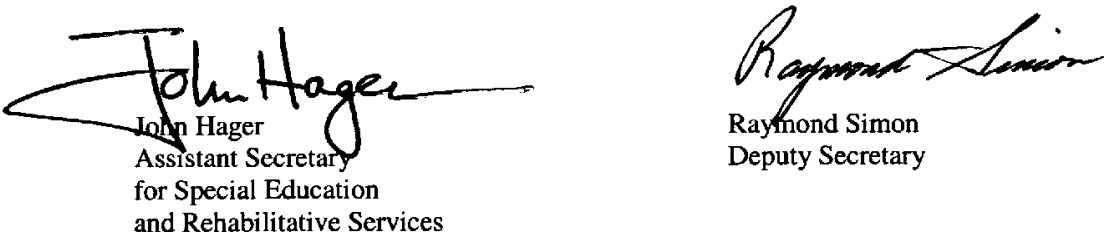

and Rehabilitative Services 


\section{Appendix III: GAO Contact and Staff Acknowledgments}

\section{GAO Contact}

Staff

Acknowledgments
Marnie Shaul, (202) 512-7215, shaulm@gao.gov

Harriet Ganson (Assistant Director) and Arthur T. Merriam Jr. (Analyst-inCharge) managed all aspects of the assignment. Katharine Leavitt and Scott Spicer made significant contributions to this report, in all aspects of the work. In addition, Sheranda Campbell contributed to the initial design of the assignment, Carolyn Boyce provided technical support, Daniel Schwimer provided legal support, and Scott Heacock assisted in the message and report development. 


\section{Related GAO Products}

Charter Schools: To Enhance Education's Monitoring and Research, More Charter School-Level Data Are Needed. GAO-05-5. Washington, D.C.: January 12, 2005.

No Child Left Behind Act: Improvements Needed in Education's Process for Tracking States' Implementation of Key Provisions. GAO-04-734. Washington, D.C.: September 30, 2004.

No Child Left Behind Act: Additional Assistance and Research on Effective Strategies Would Help Small Rural Districts. GAO-04-909. Washington, D.C.: September 23, 2004.

Special Education: Additional Assistance and Better Coordination Needed among Education Offices to Help States Meet the NCLBA Teacher Requirements. GAO-04-659. Washington, D.C.: July 15, 2004.

No Child Left Behind Act: More Information Would Help States Determine Which Teachers Are Highly Qualified. GAO-03-631. Washington, D.C.: July 17, 2003.

Title I: Characteristics of Tests Will Influence Expenses; Information Sharing May Help States Realize Efficiencies. GAO-03-389. Washington, D.C.: May 8, 2003. 
The Government Accountability Office, the audit, evaluation and investigative arm of Congress, exists to support Congress in meeting its constitutional responsibilities and to help improve the performance and accountability of the federal government for the American people. GAO examines the use of public funds; evaluates federal programs and policies; and provides analyses, recommendations, and other assistance to help Congress make informed oversight, policy, and funding decisions. GAO's commitment to good government is reflected in its core values of accountability, integrity, and reliability.

Obtaining Copies of GAO Reports and Testimony

\section{Order by Mail or Phone}

The fastest and easiest way to obtain copies of GAO documents at no cost is through GAO's Web site (www.gao.gov). Each weekday, GAO posts newly released reports, testimony, and correspondence on its Web site. To have GAO e-mail you a list of newly posted products every afternoon, go to www.gao.gov and select "Subscribe to Updates."

The first copy of each printed report is free. Additional copies are $\$ 2$ each. A check or money order should be made out to the Superintendent of Documents. GAO also accepts VISA and Mastercard. Orders for 100 or more copies mailed to a single address are discounted 25 percent. Orders should be sent to:

U.S. Government Accountability Office

441 G Street NW, Room LM

Washington, D.C. 20548

To order by Phone: Voice: (202) 512-6000

TDD: (202) 512-2537

Fax: (202) 512-6061

\section{To Report Fraud, Waste, and Abuse in Federal Programs}

\section{Contact:}

Web site: www.gao.gov/fraudnet/fraudnet.htm

E-mail: fraudnet@gao.gov

Automated answering system: (800) 424-5454 or (202) 512-7470

Gloria Jarmon, Managing Director, JarmonG@gao.gov (202) 512-4400 U.S. Government Accountability Office, 441 G Street NW, Room 7125 Washington, D.C. 20548 